$\begin{array}{lr}\text { Љиљана Ђурић* } & \text { https://doi.org/10.18485/zivjez.2018.38.1.8 } \\ \text { Филолошки факултет } & \text { 81'246.2(497.11) } \\ \text { Универзитет у Београду } & \text { Прегледни рад }\end{array}$

\title{
ДВОЈЕЗИЧНА НАСТАВА У СРБИЈИ: ПОГЛЕД У БЛИЖУ И ДАЉУ ПРОШЛОСТ
}

И данас се у Србији двојезична настава посматра као педагошка иновација, иако се у континуитету остварује већ 14 година. Са становишта анализе језичких образовних политика као јавних политика, та чињеница отвара неколика питања, од којих је једно улога различитих актера у процесу њеног увођења, остваривања и вредновања. Евидентирањем најважнијих домаћих искустава која су претходила увођењу двојезичне наставе 2004. године у две београдске образовне институције и анализом одређених аспеката тих искустава, овај рад тежи да одговори на питање учинка различитих актера у развијању тог модела наставе, али и да тиме што ће указати на проблеме који се јављају као константа, то јест који до сада нису ефикасно решени, поглед у прошлост стави у функцију будућег развоја двојезичне наставе.

Кључне речи: анализа језичких образовних политика, јавне политике, двојезична настава, Србија, улога актера, искуства из прошлости, нерешена питања

\section{1. Специфичности положаја двојезичне наставе у Србији: уводне напомене}

Пре близу једне и по деценије, тачније, 1. септембра 2004. године, двојезична настава у којој се користе српски и страни језик уведена је у две београдске школе: у ООШ „Владислав Рибникар“ започело се са реализацијом наставе на српском и на француском, а у Трећој београдској гимназији наставе на српском

ljiljana.djuric.55@gmail.com 
Љиљана Ђурић

и француском и на српском и италијанском језику. У следећим годинама, број школа са двојезичним одељењима увећавао се, као и број језичких комбинација - како са српским тако и са неким језицима националних мањина као наставним. Према подацима за 2017/2018. школску годину Министарства просвете, науке и технолошког развоја Републике Србије ${ }^{1}$, данас се двојезична настава у Србији изводи у 14 основних и 16 средњих школа, од тога у 28 на српском, по једна на мађарском и на хрватском, у комбинацији са неким од језика који се у нашем систему образовања уче као страни, са изузетком, за сада, шпанског језика.

С обзиром на то, сада већ значајно искуство, легитимно је запитати се зашто се у нашој средини двојезична настава и даље посматра као педагошка иновација² ${ }^{2}$ утолико пре што је

1 Захваљујемо доц. др Катарини Завишин што је поделила с нама податке добијене од Министарства

2 Као показатеље да се двојезична настава у нас и даље сматра педагошком иновацијом чије предности тек треба доказати, наводимо следеће чињенице:

1. За увођење двојезичне наставе, у складу са Правлиником о ближим условимаза остваривање двојезичне наставе, «Службени гласник РС» 105/2015, 50/2016. и Правилником о допунама Правилника о ближим условима за остваривање двојезичне наставе, «Службени гласник РС» 35/2017, заинтересоване школе Министарству просвете морају поднети захтев за добијање сагласности за остваривање двојезичне наставе, а уз захтев доставити елаборат који садржи читав низ елемената, међу којима:

- разлоге и оправданост увођења двојезичне наставе;

- циљеве и исходе реализације двојезичне наставе; детаљан опис модалитета начина реализације наставе;

- опис постојећих услова у школи, као и мере за одрживост програма, укључујући очекивану подршку (локална самоуправа, друго правно или физичко лице).

2. Поред тога, двојезична настава тема је докторских дисертација (на пример, теза Теоријске основе и критичка анализа CLIL наставе на француском и на српском језику у средњој школи у Србији Лидије Пасуљевић Швимел, под менторством проф. др Јулијане Вучо, одбрањена је 13. јула 2018. године на Филолошком факултету Универзитета у Београду), научних и стручних скупова (на пример, LIEC18 BEING BILINGUAL у организацији Савремене гимназије, одржан је 19. маја 2018. године у Београду; напомињемо да смо део истраживања који представљамо у овом раду изложили управо на том скупу) и друго. 
неких домаћих искустава, мање или више познатих стручној и научној јавности, било и у прошлости: на први поглед делује као да систем образовања Србије не успева ни да безрезервно прихвати, нити да дефинитивно одбаци тај модел наставе.

Покушај да се разуме специфичан положај двојезичне наставе у Србији и да се он објасни са становишта анализе јавних политика отвара могућност различитих праваца проучавања. Определили смо се да као окосницу ове дијахронијске анализе узмемо улоге актера укључених у фазе осмишљавања, имплементирања и евалуације двојезичне наставе, будући да на тај начин можемо стећи увид у њихове најбитније аспекте. Посебну пажњу посвећујемо односу учинка просветних власти и (страних) институција које су подржавале те пројекте с једне, и учинка наставника укључених у двојезичну наставу с друге стране, јер нам је почетна хипотеза у истраживању била да трајност пројекта у значајној мери зависи управо од односа оптерећења наставника и спремности просветних власти да то оптерећење вреднују на адекватан начин.

Истраживање се бави, дакле, кратким епизодама посматраним у релативно дугом периоду (око 45 година), што значи да смо примењивали комбиновани приступ тако што смо прво анализирали краткорочне стратешке интеракције актера, а затим, стављајући их у дугорочну перспективу, трагали за евентуалним променама узајамног односа актера. Истраживање се ослања на исказе учесника у пројектима, осим када је реч о првом послератном искуству, започетом 1957. године, за чију анализу користимо текстове објављене петнаестак година после укидања огледа, а чији су аутори били његови значајни актери.

У овом раду ћемо стога:

- дати преглед историјских искустава и њихових карактеристика,

- приказати, колико то извори омогућују, најрелевантније актере и њихове улоге,

- издвојити проблеме који су константно присутни у досадашњим искуствима, а који, уколико се њиховом решавању не приступи темељно, могу угрозити трајност данас акутелног модела. 


\section{2. Двојезична настава у систему образовања Србије}

За аналитичара језичких образовних политика као јавних политика - схваћених, у складу са дефиницијом Милера и Сирела, као „нормативни оквири акције који теже да успоставе локалне поретке комбинујући елементе јавне моћи и елементе експертизе" (in Ван Зантен 2005: 25), или оном Менија и Тенига, по којима је јавна политика „све оно што државни актери одлуче да предузму или да не предузму, што стварно учине или не учине“ поводом одређеног питања за које се процењује да је од јавног значаја (Мени и Тениг 1989: 134) двојезична настава вишеструко је занимљива и изазовна јер ремети:

- устаљена виђења односа језика и образовања карактеристична за државе претежно стандарднојезичке културе, као што су многе европске земље, укључујући Србију (Филиповић 2014; Филиповић 2009),

- устаљена виђења значаја наставних садржаја нејезичких предмета у државама чија се образовна традиција темељи на наставним програмима претежно енциклопедијског типа.

Двојезична настава наводи на преиспитивање когнитивне и идентитетске функције језика наставе, приоритета садржаја нејезичких наставних предмета у односу на језик којим се тај садржај саопштава, улоге наставника (страног језика, нејезичког наставног предмета, матерњег језика / језика наставе) и његове компетенције („свезнајући“ наставник, сарадник у учењу, модератор итд.) и друго.

Двојезична настава се, међутим, јавља и у таквим срединама. То се десило и у Србији, и то у неколико наврата пре 2004 , године увођења двојезичне наставе на српском и француском језику у VII и VIII разред ООШ “Владислав Рибникар“ у Београду и двојезичне наставе на српском и француском језику и на српском и италијанском језику у Трећу београдску гимназију почев од првог разреда. 
У овај времеплов кренућемо обрнутом хронологијом, од искуства које је непосредно претходило 2004, па све даље у прошлост.

\section{3. Послератна искуства}

Школске године 2002/2003, на иницијативу Девете београдске гимназије «Михаило Петровић-Алас» и Француског културног центра у Београду ${ }^{3}$ уведено је интегрисано учење француског језика и садржаја биологије. У оквиру додатне наставе, у поменутој гимназији држана је настава биологије на француском језику за заинтересоване ученике првог разреда. Професор француског језика ${ }^{4}$ који је реализовао ту наставу бирао је у сарадњи са професором биологије занимљиве теме из наставног програма. Ученици су имали могућност праћења додатних часова француског језика са француским лектором. Француски културни центар обећао им је студијско путовање у Француску, али се оно није остварило (Ђурић 2006: 31, 32).

Упркос мотивисаности ученика и наставника и добрих резултата у које се наставник уверио путем тестирања, овај пројекат није настављен, а од француске стране нисмо добили објашњење те одлуке, иако смо га у то време тражили у више наврата. Будући да су јула 2002. године Влада Републике Француске и Савезна влада Републике Југославије потписале Конвенцију о финансирању Пројекта Помоћ Савезној Републици Југославији за обнову образовног система, можемо претпоставити да поменути модел двојезичне наставе није у довољној мери одговарао могућностима које је Конвенција пружала, тачније, да је био исувише скромно замишљен за оквир који је пружао знатно шире могућности.

(На овом месту ћемо узгред поменути и једну иницијативу која се у неколико наврата појављивала током вишегодишње

3 Данас Француски институт у Србији.

4 Реч је о колеги Радету Котлајићу, коме овом приликом захваљујем на пренесеном искуству. 
паузе у развијању домаћег модела двојезичне наставе. Реч је о неуспелим покушајима оснивања српско-француске гимназије. Двојезичној настави на српском и француском језику наиме, онаквој каква је уведена 2004. године, претходили су, пре и непосредно после санкција ${ }^{5}$, бројни разговори француске стране и представника Министарства просвете Републике Србије о оснивању српско-француске гимназије. Иако су такве гимназије - у којима су наставни језици француски и језик дате државе - успешно имплементиране у многим земљама 6 , деведесетих година XX века у Србији није постојао друштвено-политички амбијент потребан за успешну реализацију тог пројекта који је убрзо и напупштен.)

Године 1966. уведена је интензивна настава (10 часова недељно) француског језика на раном узрасту ${ }^{7}$, почев од првог разреда, у београдску ОШ „Слободан Принцип Сељо“, касније ОоШ „Владислав Рибникар“. Поред наставе језика, часови физичког, ликовног и музичког васпитања држани су једно време на француском језику; наставу тих предмета, која се одвијала у оквиру редовне наставе, држали су професори француског језика, што је било у колизији са правилником о стручној спреми. Пошто наставници француског језика нису били квалификовани за извођење наставе из тих наставних предмета, од овога се убрзо одустало. Од тада, ученици у свим разредима наведене школе имају по шест часова француског језика недељно.

5 Разговори су вођени почетком деведестих година, и прекинути када је Савет безбедности Уједињених нација увео санкције Савезној Републици Југославији (маја 1992. године до новембра 1996). После укидања санкција САД и Европске уније, октобра 2000, разговори су обновљени, али идеја није заживела.

6 То се односи како на европски континент тако и на остале континенте. Претраживач Интернета издваја следеће гимназије: Lycée franco-libanais, Lycée franco-allemand, Lycée franco-hellenique, Lycée franco-mexicain, Lycée franco-qatarien, Lycée franco-américain итд.

7 О овом значајном, троструком, огледу којим се уводи рано, интензивно и учење страног језика кроз двојезичну наставу у формални систем образовања у Србији више у Ђурић 2018. 
$1057^{8}$. године уведена је настава географије на немачком језику у експерименталну гимназију „Тодор Дукин“ у Бечеју ${ }^{9}$ а 1959, настава географије и на француском језику. Те године, настава историје изводила се на немачком језику. И поред извесних тешкоћа организационе природе, али и оних у вези са језичком компетенцијом наставника нејезичких наставних предмета ${ }^{10}$, модел се успешно ширио. Како смо то приказали на другом месту (Ђурић 2016: 173, 178, 216, 217), резултати рада у гимназији „Тодор Дукин“ у Бечеју и у Огледној гимназији „Иво-Лола Рибар“ у Сремској Митровици објављени су под насловом 'Експериментално учење географије на страном језику у II разреду гимназије', те су, „после извршених коректура добили дефинитивни облик и примењени у седам одељења, експерименталних и контролних, у Бечеју, Сремској Митровици, Новом Саду и Руми." Упркос позитивним резултатима овог и још неких огледа у гимназијама, „до дисеминације ових искустава није дошло, што се објашњава чињеницом да у школама претходно треба савладати низ тешкоћа организационе, кадровске и материјалне природе." (Кркљуш и Мелвингер 1980: 82)

Свеобухватна реформа образовања чији је правни темељ Опћи закон о школству (1958), као и „Велика флуктуација кадра у огледним школама, изостанак давања утврђене новчане награде наставницима укљученим у огледе итд." (Ђурић 2016: 173, 174, према Кркљуш и Мелвингер 1980: 75-119), свакако су такође допринеле гашењу овог експеримента.

8 Ову годину узимамо на основу текста са званичног сајта Гимназије. Податак се не поклапа у потпуности са оним који налазимо у основном извору који користимо, по којем је Гимназија постала огледна 1959. године (Кркљуш и Мелвингер 1980: 72, напомена 8).

9 Данас Гимназија Бечеј.

10 „Сондажна настава географије на француском језику показала је да нису потпуно реалне поставке од којих се пошло“, то јест да је „требало створити услове у којима би се страни језик приближио функцији коју у школи има матерњи језик“ (Кркљуш и Мелвингер 1980: 82). 


\section{4. Искуства између два светска рата}

Још један пример двојезичне наставе (која се у то време није тако звала) представља важно искуство које не треба заборавити: реч је о страним приватним школама које су у периоду између два светска рата могле образовати наше ученике ${ }^{11}$ у складу са законима Краљевине Срба, Хрвата и Словенаца, касније Краљевине Југославије. У Београду је тада било неколико приватних страних основних школа и гимназија, грчка, јеврејска, чешка итд, „међу којима је једна од најугледнијих била Француско-српска школа“ (Николова 2008: 39), чувена школа „Сен Жозеф“, која је право рада од Министарства просвете Краљевине СХС добила 1926. године. Поред основне школе, током петнаестогодишњег постојања, основани су забавиште, као и мушка и женска полугимназија.

На основу ђачких књижица ученика Француско-српске основне школе види се да је настава остваривана:

- $\quad$ на српском језику - веронаука, српски језик, земљопис и историја (по програму и уџбеницима за српске државне школе);

- на француском језику - lecture, grammaire, vocabulaire, récitation, calcul, calligraphie, travail manuel, gymnastique, chant.

„Наставу на српском језику, исту као у државним основним школама, држали су искључиво наставници и наставнице с југословенским држављанством. Часове ручног рада, цртања, лепог писања, певања и гимнастике водиле су милосрдне сестре или браћа, а настава из рачуна и геометрије организована је тако да су, од прописана четири, два одржавана на српском, а два на француском језику ${ }^{12 “}$ (Николова 2008: 58, 59).

11 Оснивање приватних основних школа укинуто је Законом о народним школама из 1929. (члан 164), али већ основане приватне народне школе могле су да наставе са радом под условом да „се најдаље за четири месеца после ступања наснагу овог Закона у свему саобразе његовим прописима."

12 Подвлачи Љ.Ђ. 
ДВОЈЕЗИЧНА НАСТАВА У СРБИЈИ: ПОГЛЕД У БЛИЖУ И ДАљУ ПРОШЛОСТ

Ученици школе „Сен Жозеф“ имали су већи укупан фонд часова од ученика државних српских школа, и то за осам часова у првом разреду, да би се разлика постепено смањивала. Највећи број часова француског језика био је у првом разреду (чак 11), а најмањи у четвртом (9).

\section{5. Шта нам је остало од тих искустава}

Послератна искуства, којима је заједничка неселективност - двојезичну наставу пратили су сви ученици дате гимназије или датог одељења, и сви ученици ОШ „Слободан Принцип Сељо“ односно ООШ „Владислав Рибникар“, а 2002/2003. сви заинтересовани ученици - омогућила су стварање законске основе за двојезичну наставу; рекло би се, такође, да су код бивших ученика остали чврсти ставови о томе шта је добар модел двојезичне наставе, а код наставника који су радили у двојезичној настави одређене недоумице и свест о проблемима. Даћемо неколико примера:

- Законска основа обезбеђена је Законом о средњем образовању из 1967. године, у чијем је члану 21 утврђено следеће: „У гимназијама се може организовати настава на страним језицима из појединих наставних предмета - групе предмета или свих наставних предмета“ (Просветни гласник 1967: 155-156); законска могућност организовања двојезичне наставе, иако је ретко коришћена у пракси до 2004. године, задржала се и у касније донесеним законима о средњем образовању.

- У ОШ „Слободан Принцип Сељо“, која је постала ООШ „Владислав Рибникар“ спајањем са ОШ „Алекса Шантић“ 1976. године, укинута је двојезична настава, и задржана је само интензивна настава француског језика од I разреда, са по шест часова недељно; међу оним бившим ученицима који су похађали наставу по првобитном моделу и са којима смо имали прилике да разговарамо, остало је уверење да је тај први приступ био 
изванредно ефикасан, штавише, „неупоредиво бољи систем“13 од оног који је настао после укидања наставе нејезичких предмета на француском, јер „до V разреда ученици нису чули реч српског језика од наставника који су предавали француски језик и друге предмете на француском језику, те су с њима спонтано комуницирали искључиво на француском“. Поред тога, на часовима француског језика, наставници су обрађивали најважније појмове које су ученици савладали из математике и других наставних предмета.

- Међу наставницима француског језика који су тада, поред наставе француског језика, држали и наставу нејезичких предмета, остала је свест о проблемима ${ }^{14}$ :

- правне природе - по правилнику о стручној спреми нису били квалификовани за држање те наставе, те су се осећали „као у илегали“ и били у извесном страху за свој положај;

- $\quad$ методолошке природе - сусретали су се са бројним недоумицама, нпр. треба ли дати предност језичком аспекту или садржајима датог наставног предмета, како предавати предмет за који нису били стручни итд.

Разуме се да је искуство из периода између два светска рата сасвим другачије природе, већ и на основу чињенице да су школу „Сен Жозеф“ уписивала деца припадници тадашње

13 У питању је мишљење десет бивших ученика са којима смо водили разговор о овој теми. Посебно истичемо мишљење Аните Ђурић (чије смо речи у горњем пасусу цитирали), која је од 1972. године похађала наставу по првобитном моделу, а после постала професор француског језика у истој школи. Колегиница Анита Ђурић има утисак да сви бивши ученици њене генерације са којима је у контакту и данас могу да комуницирају на француском језику, без обзира на професију којом се баве.

14 Ово мишљење пренеле су нам колегинице Весна Фила, и сама наставник француског језика, касније дугогодишњи директор Школе, и Анка Ивковић, такође дугогодишњи наставник француског језика у Школи, којима овом приликом захваљујемо. Напомињемо да је Анка Ивковић приказала овај оглед на међународном конгресу о учењу француског језика који је 1992. одржан у Барселони. Рад, нажалост, није сачуван. 
друштвене елите ${ }^{15}$ јер се школарина плаћала ${ }^{16}$. Очекивано је, стога, да је елитно образовање давало и одговарајуће резултате. „Кроз Француско-српску школу Сен Жозеф током петнаест година, колико је она постојала, прошло је око 3000 ђака. Њени учитељи, професори и васпитачи својим знањем и моралним ставовима утицали су у великој мери на формирање многих будућих уметника и научника, стваралаца српске просвете, културе и науке. Међу њима су били Олга Јеврић, вајар, Милка Ивић, лингвиста, Иван Антић, архитекта, Драгољуб Гостушки, композитор, Милутин Стефановић, хемичар, Милош Велимировић, музиколог, Мирон Флашар, историчар књижевности, и многи други.“ (Николова 2008: 97) Образовање у страној школи није, дакле, довело до губитка идентитета ученика, како се неретко стаховало и страхује данас, штавише, рекло би се да је код њих развило специфичну врсту патриотизма, то јест жеље да се досегну врхунски нивои у изабраним професијама.

Важном тековином овог искуства можемо сматрати и то што су неки од бивших ученика били међу иницијаторима огледног учења француског језика у ОШ „Слободан Принцип Сељо“ (Ђурић 2018). Са становишта нашег истраживања, од оног што је остало после тог искуства, најважније јесте уверење да је овај специфичан вид наставе дао одличне резултате, ми бисмо данас рекли, омогућио ученицима да стекну и комуникативну, и академску и интеркултурну компетенцију: „Добро организовано паралелно учење свих појмова и на српском и на француском језику, уз велико залагање страних и домаћих

15 Можемо ову чињеницу довести у везу са тезом Клода Тришоа који прави разлику између елита у западној Европи - које су се од народних маса, школованих на националном језику, издвајале по знању класичних језика, и елита источне и централне Европе - чији су национални језици релативно скоро стекли тај статус и које су своју децу слале у школе у којима се настава изводила у потпуности или делом на француском, немачком или енглеском језику. Као једну од првих двојезичних школа Тришо помиње гимназију у Нафплију (привремена престоница, од 1829. до 1934, новостворене Грчке), која је основана 1833, затим двојезичне школе у Бугарској и Турској, основане 1868. године (Тришо 2008: 47).

16 „За школарину и интернатски смештај давало [се] 1.200 до 1.500 динара, а то је у оно време био велики износ [...]“ (Николова 2008: 69). 
Љиљана Ђурић

учитеља и професора, давало је високе резултате код ученика. У учењу су примењиване савремене методе, а принцип очигледности био је спровођен и код деце предшколског узраста, која су страни језик усвајала сликовном методом. Друштвени живот и ваннаставне активности, школске приредбе и излети доприносили су јачању колективног духа међу ученицима и повезивали две различите културе - српску и француску." (Николова 2008: 91)

\section{6. Актери у описаним (послератним) искуствима и њихове улоге}

Језичке образовне политике, као и јавне политике уопште, осмишљавају се, остврују и вреднују уз учешће значајног броја актера. У свим процесима, па тако и у иновативним, учествују просветне власти као доносиоци одлука, директори школа, који у доношењу одлука учествују саветодавно, у својству познавалаца праксе, и наставници, најчешће као реализатори. Родитељи ученика могу бити на известан начин укључени, било преко својих представника у школским одборима или представника својих удружења, било као угледни (или политички моћни) појединци. Значајни актери могу бити и експерти, чланови високообразовних институција, као и струковна и друга удружења.

Прва груба подела дели актере на државне и недржавне. За потребе овог истраживања користићемо нешто другачију типологију, у складу са конкретним улогама у горе описаним искуствима ${ }^{17}$ :

- доносиоци одлука на крају процеса осмишљавања одређених решења: министри са својим непосредним са-

17 Због обима рада, изостављамо неке категорије актера, на пример кориснике (ученици, родитељи), или евалуаторе који се, у конкретним искуствима које смо представили, не појављују као екстерни актери (евалуацију, када је било, најчешће су вршили државни актери или сами наставници укључени у пројекат). 
радницима, запослени у Министарству просвете, у заводима и секретаријатима (републички и покрајински ниво) одговорни за питања наставе страних језика;

- пружаоци подршке (у осмишљавању пројекта, опремању школа, усавршавању наставника и друго): стране институције које раде на територији Србије, то јест амбасаде, културни центри, институти и слично;

- непосредни спроводиоци одлука, то јест реализатори пројекта: наставници језичких и нејезичких наставних предмета.

Сва три приказана искуства имала су релативно кратак век трајања. Разлоге њиховог обустављања већ смо навели у делу рада у којем смо их представили. Покушаћемо сада да у табеларном приказу размотримо удео доносилаца одлука, пружалаца подршке и наставника реализотора у развоју двојезичне наставе.

\section{УДЕО АКТЕРА У РАЗВОЈУ ДВОЈЕЗИЧНЕ НАСТАВЕ}

\begin{tabular}{|c|c|c|c|}
\hline $\begin{array}{r}\text { АКТИВНОСТИ } \\
\text { УЧИНАК } \\
\text { АКТЕРА } \\
\text { ИСКУСТВА }\end{array}$ & $\begin{array}{c}\text { ДОНОСИОЦИ } \\
\text { ОДЛУКА }\end{array}$ & $\begin{array}{c}\text { ПРУЖАОЦИ } \\
\text { ПОДРШКЕ }\end{array}$ & $\begin{array}{l}\text { НАСТАВНИЦИ } \\
\text { РЕАЛИЗАТОРИ }\end{array}$ \\
\hline 2002/2003. & / & $\begin{array}{c}\text { - Француски } \\
\text { културни центар } \\
\text { дао иницијативу; } \\
\text { - доделио лектора } \\
\text { Француза. }\end{array}$ & $\begin{array}{c}\text { - Наставник француског } \\
\text { језика учествовао у } \\
\text { давању иницијативе; } \\
\text { - у сарадњи са колегом, } \\
\text { вршио избор садражаја } \\
\text { из биологије, припремао } \\
\text { (планирао, израђивао / } \\
\text { прилагођавао наставне } \\
\text { материјале); } \\
\text { - држао додатну наставу; } \\
\text { - вредновао постигнућа } \\
\text { ученика. }\end{array}$ \\
\hline
\end{tabular}


Љиљана Ђурић

\begin{tabular}{|c|c|c|c|}
\hline 1966. & $\begin{array}{c}\text { - Влада СФРЈ } \\
\text { потписала } \\
\text { споразум } \\
\text { Владом } \\
\text { Републике } \\
\text { Француске; } \\
\text { - Републички } \\
\text { секретаријат за } \\
\text { образовање и } \\
\text { културу СР Србије } \\
\text { одобрио; } \\
\text { - Со Врачар дала } \\
\text { сагласност; } \\
\text { - Просветно- } \\
\text { педагошки } \\
\text { заводу Београду } \\
\text { помогао у } \\
\text { имплементацији; } \\
\text { - држава } \\
\text { финансирала } \\
\text { наставу кроз } \\
\text { личне дохотке } \\
\text { наставника. }\end{array}$ & $\begin{array}{c}\text { - Француска } \\
\text { амбасада и } \\
\text { Француски } \\
\text { културни центар } \\
\text { помагали } \\
\text { у опреми и } \\
\text { уџбеницима; } \\
\text { - доделили } \\
\text { учитеља } \\
\text { Француза; } \\
\text { - додељивали } \\
\text { стипендије за } \\
\text { наставнике. }\end{array}$ & $\begin{array}{c}\text { - Наставници француског } \\
\text { језика држали наставу } \\
\text { француског језика на } \\
\text { раном узрасту, по аудио- } \\
\text { визуелној методи Frère } \\
\text { Jасqиеs; } \\
\text { - наставници француског } \\
\text { језика држали наставу } \\
\text { ликовног, музичког и } \\
\text { физичког васпитања } \\
\text { на француском језику: } \\
\text { уз консултације са } \\
\text { учитељима, припремали } \\
\text { (планирали, израђивали / } \\
\text { прилагођавали наставне } \\
\text { материјале); } \\
\text { - вредновали постигнућа } \\
\text { ученика; } \\
\text { - анкетирали родитеље; } \\
\text { - организовали приредбе; } \\
\text { - примали госте из } \\
\text { Француске, поред } \\
\text { осталих, супругу } \\
\text { француског председника } \\
\text { Жискара Д`Естена и } \\
\text { Јованку Броз². }\end{array}$ \\
\hline 1957. & $\begin{array}{c}\text { - Секретаријат } \\
\text { за просвету } \\
\text { и културу } \\
\text { Аутономне } \\
\text { покрајине } \\
\text { Војводине дао } \\
\text { иницијативу, то } \\
\text { јест: } \\
\text { - осмислио оглед } \\
\text { - имплементирао } \\
\text { га } \\
\text { - пратио и } \\
\text { вредновао } \\
\text { - вршио } \\
\text { дисеминацију. }\end{array}$ & / & $\begin{array}{c}\text { - Наставници географије } \\
\text { и историје држали } \\
\text { наставу својих } \\
\text { наставних предмета на } \\
\text { немачком односно на } \\
\text { француском језику, то } \\
\text { јест: } \\
\text { - припремали се, а потом } \\
\text { и држали наставу на } \\
\text { језику који су учили као } \\
\text { страни; } \\
\text { - вредновали } \\
\text { постигнућа ученика; } \\
\text { - учествовали у } \\
\text { унапређивању } \\
\text { огледа ради његове } \\
\text { дисеминације. }\end{array}$ \\
\hline
\end{tabular}

Као што се из табеле може видети, државни актери имали су значајног удела у искуствима из 1957. и 1966. Та два пројекта су и званично били огледи, те се без учешћа просветних власти нису могли ни уводити ни спроводити; оба треба посматрати у контексту децентрализације која „доводи до јачања иниција- 
тива школских органа и самих школа“ (Комисија за реформу школства 1957: 12), а прво искуство и у контексту припрема за свеобухватну реформу образовања, будући да је у изабраним школама требало проверити „вредност појединих решења и ставова у тражењу и изграђивању концепције реформисане школе“ (Кркљуш и Мелвингер 1980: 69). Сасвим другачија је ситуација са искуством из 2002/2003. године, за које није било потребно одобрење просветних власти, с обзиром на то да је сваки наставник слободан да врши избор садржаја на основу којих ће остваривати додатну наставу. То се последње искуство, међутим, показало и као најкраткотрајније, оно са најнижим степеном импакта на систем образовања, што је неоправдано имајући у виду бројне практичне предности тог модела и могућности његовог прилагођавања локалним потребама и кадровским могућностима сваке средине.

На основу анализе извора, констатујемо да се у сва три случаја јављао известан број истоветних проблема, на пример:

- недостатак адекватних наставних материјала,

- недовољна (?) компетенција наставника, формална (да ли испуњавају услове правилника о стручној спреми) и суштинска (језичка и методичка),

- питање преласка са огледа на сталан модел,

- одсуство екстерног вредновања итд.

Јавља се такође очигледна неуравнотеженост између обавеза наставника и њихове скромне (или непостојеће) улоге у осмишљавању пројекта, а поготово између њиховог великог ангажовања и одсуства адекватне награде за изузетне напоре којима су константно изложени: ни у једном случају које смо разматрали, наиме, није било реализовано материјално награђивање, нити смањење фонда часова, како се такође могао разрешити проблем и дати подстрек наставницима укљученим у пројекат. Њихова једина награда били су резултати ученика и понеки одлазак на стручно усавршавање, због чега су многи изгубили мотивацију. Тај однос према наставницима реализаторима показује се као непромењен у истраживаном периоду. 


\section{7. Закључне напомене}

Наша почетна хипотеза да трајност пројекта у значајној мери зависи од односа оптерећења наставника и спремности просветних власти да вреднују то оптерећење потврђено је резултатима истраживања. Као значајан фактор трајности пројекта издвојили смо и степен ангажовања доносилаца одлука и пружалаца подршке. Висок степен постигнућа ученика, међутим, изгледа да има одређени утицај, али са одложеним дејством: ти резултати нису успели да спрече укидање пројеката, али су допринели покретању нових, сличних иницијатива.

Осим проблема које смо већ издвојили као константно присутне, треба поменути и невидљиве отпоре овом моделу наставе који нису били предмет нашег истраживања, а који указују на опстајање бројних предрасуда о којима се у стручној и научној јавности не говори довољно. Доживљена некад као угрожавајућа (доводи у питање, на пример, једнакост ученика јер се остварује у привилегованим условима и најчешће у елитним школама; угоржава, наводно, ученика јер ће га учење нејезичких наставних предмета на страном језику онемогућити да квалитетно савлада садржаје или ће га тај модел наставе усмерити на студије у некој другој земљи), хваљена с друге стране као најбољи начин образовања за опстанак малих Европљана, као врста образовања који у себи носи вредности као што су толеранција, комплексност, радозналост (Лијети 1994), двојезична настава кристалише многе животне тензије које и иначе постоје у друштву, па јој зато треба посветити посебну пажњу у даљим истраживањима, како у области глотодидактике тако и у области анализе језичких образовних политика.

\section{ЛИТЕРАТУРА}

Ван Зантен 2005: Van Zanten, A. Les Politiques d'éducation. Paris : PUF. Ђурић 2018: Đurić, Lj. Les langues vivantes à l'âge précoce en Serbie : Quelle(s) influence(s) 
de l'enseignement non formel sur les politiques linguistiques éducatives? (Entretien avec le professeur Konstantinović).У: Вучо, J. и др (ур.) Филолошка истраживања данас, вол. 9: Рано и почетно учење страних језика у формалном образовању. Београд: Филолошки факултет. У штампи.

Ђурић 2016: Ђурић, Љ. Страни језищи у образовној политици Србије. Београд: Филолошки факултет Универзитета у Београду.

Ђурић 2006: Ђурић, Љ. Огледи и иновативни пројекти у настави француског језика. Иновације у настави. Београд: Учитељски факултет, 2006. - Стр. 28 - 40.

Комисија за реформу школства 1957: Komisija za reformu školstva. Stanje i razvoj gimnazija. Dokumentacija uz predloge za reformu školstva. Beograd: Savezni zavod za proučavanje školskih i prosvetnih pitanja.

Кркљуш и Мелвингер 1980: Krkljuš, M. i Melvinger, Z. Značaj uglednihoglednih škola i eksperimentalnih odeljenja za unapređenje vaspitanja i obrazovanja. Y: Đuričić, J, Mesaroš. M, Micić, S, Mikić, R, Žderić, M. (1980) Tri i po decenije razvoja vaspitanja i obrazovanja u SAP Vojvodini. Novi Sad: Pedagoški zavod Vojvodine, 65-119.

Лијети 1994: Lietti, A. Pour une éducation bilingue. Guide de survie à l'usage des petits Européens. Paris: Petite bibliothèque Payot.

Мени и Тениг 1989: Mény, Y. et Thoenig, J-C. Politiques publiques. Paris : PUF.

Николова 2008: Николова, М. Француско-српска школа Сен Жозеф, Београд: Педагошки музеј.

Тришо 2008: Truchot, C. Europe : l'enjeu linguistique. Paris: La documentation française.

Филиповић 2014: Филиповић, J. Теоријски концепти и специфичности језичке образовне политике. У: Филиповић, Ј. и Дурбаба, О. (ур.) Језици у образовању и језичке образовне политике. Београд: Филолошки факултет,

Филиповић 2009: Filipović, J. Moć reči. Ogledi iz kritičke sociolingvistike. Beograd: Zadužbina Andrejević. 
Љиљана Ђурић

\section{Ljiljana Đurić}

\section{L'ENSEIGNEMENT BILINGUE EN SERBIE: UN REGARD RETROSPECTIF}

\section{Résumée}

Aujourd'hui encore, l'enseignement bilingue est perçu en Serbie comme une innovation pédagogique, bien qu'il y soit implanté de façon continue depuis 14 ans. Du point de vue de l'analyse des politiques linguistiques éducatives en termes de politiques publiques, ce fait nous pousse à nous poser un certain nombre de questions, parmi lesquelles celle du rôle des acteurs (décideurs, partenaires-soutiens étrangers, enseignants-réalisateurs) dans les processus d'introduction, de réalisation et d'évaluation de ce modèle d'enseignement.

En récapitulant les expériences les plus importantes qui ont précédé, en Serbie, l'introduction, en 2004, de l'enseignement bilingue dans deux établissements scolaires de Belgrade (suivie par d'autres établissements dans la capitale et en province, pour arriver, de nos jours, à une trentaine d'écoles primaires-collèges et de lycées bilingues ou à sections bilingues), et en soulignant certains aspects de ces expériences relativement éphémères, cet article cherche à mettre en lumière les rôles respectifs et les interactions stratégiques des acteurs dans le temps court. Placée dans une perspective de longue durée, l'analyse des tentatives empiriques de développer en Serbie un modèle d'enseignement bilingue original (d'abord en 1957 dans le lycée de Bečej, petite ville de la province autonome de Voïvodine, puis en 1966 à l'école primaire-collège " Vladislav Ribnikar » de Belgrade, et enfin en 2002/2003 au Lycée IX de Belgrade) montre que toutes ont été marquées de difficultés qui n'ont pas été résolues à ce jour et qui rendent le modèle actuel tout aussi fragile que ceux du passé.

Mots clés: l'analyse des politique linguistiques éducatives, politiques publiques, l'enseignement bilingue, Serbie, le rôle des acteurs, les expériences du passé, les difficultés irrésolues 